\title{
Terrestrial Plagioclase Olivine Clinopyroxenite as a Possible Analogue of Lunar Rocks
}

\author{
Victor Grigorievich Korinevsky*, Eugeny Victorovich Korinevsky \\ Institute of Mineralogy of the Uralian Branch of the Russian Academy of Sciences, Miass, Russia \\ Email address: \\ vgkor@mineralogy.ru (V. G. Korinevsky) \\ ${ }^{*}$ Corresponding author

\section{To cite this article:} \\ Victor Grigorievich Korinevsky, Eugeny Victorovich Korinevsky. Terrestrial Plagioclase Olivine Clinopyroxenite as a Possible Analogue of \\ Lunar Rocks. Earth Sciences. Vol. 8, No. 2, 2019, pp. 94-101. doi: 10.11648/j.earth.20190802.13
}

Received: December 10, 2018; Accepted: March 9, 2019; Published: April 29, 2019

\begin{abstract}
The article describes the mineral composition and petrochemistry of a unique ancient (more than 1848-2011 MA) igneous rock of the Urals - plagioclase olivine clinopyroxenite. These rocks are considered the oldest in the Urals. In the literature they are described under the name izrandites. They are part of the foundation of the basement of the East European platform. These rocks are highly aluminous and calcic. They are characterized by a low amount of alkalis and magnesium oxide and a comparable amount of silicon and iron. A certain petrochemical similarity is found between the izrandites and the anorthite leucogabbro, troctolite, and noritic anorthosites of lunar highlands. This similarity enhances the closeness of distribution of the minor elements, the leading role among which belongs to $\mathrm{Sr}$ and $\mathrm{Ba}$. In those and others rocks plagioclase is represented by anorthite or labrador, its amount makes up from 5-8 to 50-70\%. The izrandites are representatives of the rocks of the lower part of the Earth's crust, which in composition and absolute age can be compared with the youngest leucogabbros and troctolites of the Moon.
\end{abstract}

Keywords: Olivine Clinopyroxenite, Izrandite, Anorthosite, Leucogabbro, Urals, Earth, Moon

\section{Introduction}

The study of samples of lunar rocks brought by American cosmonauts and Soviet unmanned air vehicles made it possible to establish the similarity of the mineral and chemical composition and petrographic features of the main types of magmatic rocks of the Moon and the Earth (anorthosites, gabbroids, basalts). Now to they can be attributed the olivine clinopyroxenites. In the Urals, there are small outcrops of unusual rocks that are very rare on the Earth. One of them is the plagioclase olivine clinopyroxenite known as izrandite [22]. These are relicts of ancient rocks that occur among amphibolites in the blocks of the basement of the East European platform. The radiological age of it is older than the host rocks. The age of olivine clinopyroxenites is older than $1848 \pm 8 \mathrm{Ma}$ [25]. Many researchers have established a very large resemblance of basalts, gabbros, norites, troctolites, and anorthosites of the Earth with the same rocks of the Moon [20, 19, 21]. It is important that such rocks in the surrounding rocks in the Urals are no longer met. For a number of mineralogical and geochemical features, we see in izrandites a possible analogues one of some rocks of the lunar highlands.

\section{Analytical Procedure}

The analytical works were performed in the Institute of Mineralogy of the Russian Academy of Sciences, Miass. Samples of rock were selected by V. G. Korinevsky. Petrographic studies were carried out on microscope "Olympus" in thin sections and polished samples. Selection of minerals for analyzes was carried out manually under a binocular microscope. The minerals are confirmed by data from X-ray analysis on a DRON-2.0 diffractometer. Microprobe analyzes of all minerals were performed by V. A. Kotlyarov using the scanning electron microscope (SEM) REMMA-202M equipped LZ-5 Link Systems EDS using an acceleration voltage of $25 \mathrm{kV}$ and a focused beam $2 \mu \mathrm{m}$ in diameter, standards MINM25-53 and natural minerals. The analytical data were corrected using the Magallanes and ZAF program Chemical analyzes of the rocks were carried out by the silicate method (analyst M. N. Malyarenok). 
Abbreviations for names of minerals have received according to [33].

\section{Plagioclase Olivine Clinopyroxenite (Izrandite)}

\subsection{Geological Setting}

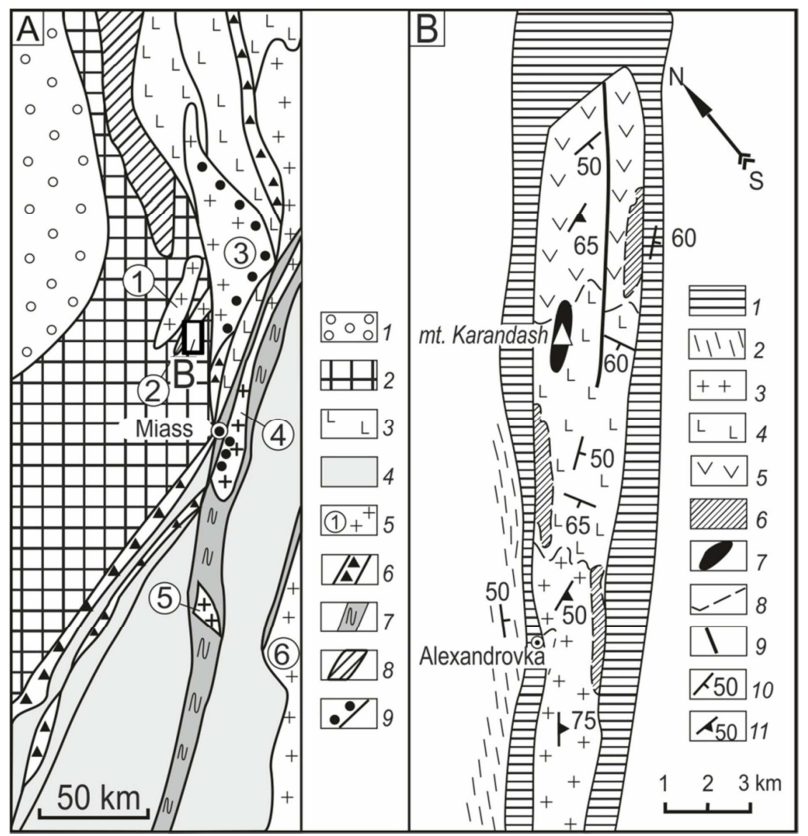

Figure 1. Position of the Aleksandrovskiy migmatite-gneissic complex in the structure of the South Urals. A - fragment of the Paleozoic-Mesozoic structural scheme for the South Urals [16]. 1 - Preduralskiy deflection; 2 Bashkir-Urals Mountains; 3 - Tagil zone; 4 - Magnitogorsk zone; 5 migmatite-gneissic-shales complexes; massifs (digits in the circles): 1 Taratash, 2 - Alexandrovka, 3 - Ufaley, 4 - Sysert-Il'menogorskiy, 5 Larinskiy, 6-Chelyabinsk-Suundukskiy; 6-zones of serpentinite mélange; 7 - crushing zones; 8 - Nyazepetrovskiy allochthon; 9 - complexes and zones of high-pressure metamorphism

B - Position of the izrandites in the Alexandrovskiy gneissic-amphibolite complex of the Proterozoic of the South Urals [23]. 1 - carbonate rocks of the Satkinskaya suite $\left(\mathrm{R}_{3}\right) ; 2$ - phyllites, shales, sandstones and gravelites of the Aiskaya suite $\left(\mathrm{R}_{3}\right) ; 3-7$ - Alexandrovskiy complex $\left(\mathrm{PR}_{1-2}\right)$ : 3 - granitegneisses; 4 - plagioclase amphibolites; 5 - plagiogneisses, gedritites, amphibolites, quartzites; 6 - apogabbroic amphibolites; 7 - izrandites and meta-izrandites; 8 - geological boundaries; 9 - tectonic boundaries; 10 elements of banding, stratification, fissility; 11 - elements of occurrence of gneissic banding.

Izrandite. is a black medium-grained massive rock, on mineral composition (clinopyroxene $65-70 \%$ of the volume, olivine $10-16 \%$, plagioclase 5-8\%, amphibole 3-8\%) plagioclase olivine clinopyroxenite responds. Izrandite is one of the oldest rocks of the Urals (more than 1848-2011 Ma $[15,25]$. They consist several isolated rock outcrops 3-6 m across among amphibolites of the Aleksandrovskiy complex, which is a part of the rocks of the Early-Proterozoic Taratash complex (Figure 1). It is considered as a projection of the foundation of the East European platform within the Uralian fault belt [22, 24]. A. M. Pystin et al. [24] showed the relict character of the izrandites, as magmatic rocks, undergoing regional metamorphism of amphibolites facies. In the vicinity of the Mount Karandash around the outcrops of izrandites $\left(55^{\circ} 31^{\prime} 44^{\prime \prime}\right.$ N, 59 $54^{\prime} 28^{\prime \prime}$ E, Figure 2) they fixed a successive transformation of the izrandites into non-feldspar amphibolites.

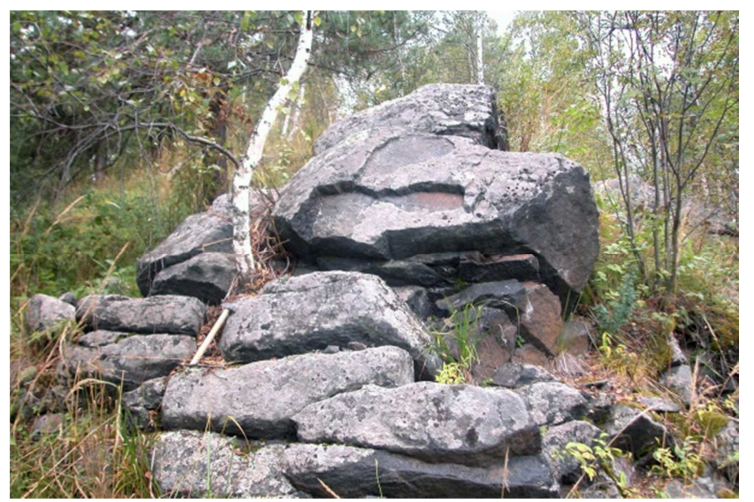

Figure 2. The outcrop of the izrandites in the upper part of the eastern slope

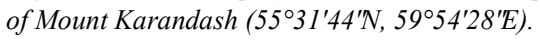

\subsection{Mineral Composition and Structure of the Izrandites}

According to the chemical composition (Table 1), the izrandites belong to the group of basic rocks. Atomic absorption analysis in them are determined (ppm): $\mathrm{Cu} 67, \mathrm{Zn}$ 63, Pb 18, Sr 64, Ba 264, Rb 11, Zr 64, Ni 117, Co 61, Cr 556. The contents of these elements fit within the boundaries of their vibrations in the rocks of the basic layered platform intrusions [27] and in the druzite complex of the Belomorsky mobile belt of the Baltic Shield [28].

Table 1. Chemical composition (wt.\%) of izrandites.

\begin{tabular}{lllllll}
\hline Probe & $\mathbf{1}$ & $\mathbf{2}$ & $\mathbf{3}$ & $\mathbf{4}$ & $\mathbf{5}$ & $\mathbf{6}$ \\
\hline $\mathrm{SiO}_{2}$ & 45.36 & 44.98 & 45.48 & 50.31 & 50.61 & 45.02 \\
$\mathrm{TiO}_{2}$ & 1.92 & 1.35 & 1.83 & 1.15 & 1.13 & 2.30 \\
$\mathrm{Al}_{2} \mathrm{O}_{3}$ & 7.42 & 5.75 & 7.49 & 3.54 & 3.79 & 7.41 \\
$\mathrm{Fe}_{2} \mathrm{O}_{3}$ & 0.83 & 2.46 & 2.78 & 1.79 & 2.30 & 2.87 \\
$\mathrm{FeO}$ & 11.30 & 10.75 & 9.95 & 6.98 & 6.52 & 10.44 \\
$\mathrm{MnO}$ & 0.25 & 0.17 & 0.17 & 0.17 & 0.17 & 0.23 \\
$\mathrm{MgO}$ & 13.70 & 17.68 & 13.72 & 18.37 & 18.41 & 13.77 \\
$\mathrm{CaO}$ & 17.18 & 14.90 & 17.02 & 16.36 & 15.73 & 16.05 \\
$\mathrm{Na}_{2} \mathrm{O}$ & 1.16 & 0.81 & 0.80 & 0.65 & 0.64 & 1.14 \\
$\mathrm{~K}_{2} \mathrm{O}$ & 0.19 & 0.18 & 0.17 & - & - & 0.13 \\
$\mathrm{H}_{2} \mathrm{O}$ & - & 0.22 & 0.20 & 0.16 & 0.22 & - \\
$\mathrm{H}_{2} \mathrm{O}^{+}$ & 0.94 & 0.26 & 0.34 & 0.42 & 0.52 & - \\
$\mathrm{CO}_{2}$ & - & - & - & - & - & - \\
$\mathrm{P}_{2} \mathrm{O}_{5}$ & - & 0.06 & traces & 0.09 & 0.09 & 0.07 \\
$\mathrm{Total}^{+}$ & 100.25 & 99.57 & 99.95 & 100.19 & 100.13 & 99.43 \\
$\mathrm{~V}, \mathrm{ppm}$ & 400 & - & - & - & - & 450 \\
$\mathrm{Co}$ & 55 & - & - & - & - & 61 \\
$\mathrm{Ni}$ & 75 & - & - & - & - & 117 \\
$\mathrm{Cr}$ & 500 & - & - & - & - & 556 \\
$\mathrm{Sr}$ & 276 & - & - & - & - & 64 \\
$\mathrm{Zr}$ & 46 & - & - & - & - & 46 \\
\hline
\end{tabular}

Note. $1-3$ - isolated rocky outcrops on Mount Karandash; 4 - hill in $1.5 \mathrm{~km}$ northeast of the village Shigir; 5 - hill in $1 \mathrm{~km}$ east of the village Shigir; 6 -

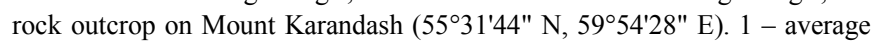
of three samples [22], $2-5$ - according to [24], 6 - according to our data (laboratory IMIN UB RAS, chemical and atomic absorption analyzes, analysts M. N. Malyarenok and T. V. Semenova). Dash - no data. 
About 2/3 of the volume of izrandites is composed of subeuhedral grains of clinopyroxene. In the rock they are placed without a certain orientation. Clinopyroxenes contain a large number of closely related finest parallel plates of ilmenite, which are grouped into bands that saturate the whole volume of pyroxene crystals in one or another quantity. Plates of ilmenite in clinopyroxene form two mutually perpendicular systems, one of which is expressed particularly clearly. In each pyroxene crystal the ilmenite plates are oriented in their own way. In dark bands, which emphasize the zoning of pyroxene, a strong condensation of the plates of ilmenite is observed (Figure 3). The lamellar character of the ilmenite intergrowths, grouping them into two systems of mutually perpendicular directions, all this indicates the phenomena of decomposition of the solid solution that appeared in pyroxene crystals. From 8 to $15 \%$ of the volume in the izrandites is accounted for by the crystals of olivine. Their diameter varies within $0.3-1.5 \mathrm{~mm}$. Large crystals have a prismatic appearance. Small crystals enclosed within the clinopyroxene grains are often isometric. Priority orientation in the olivine grains is not detected. In them there are no veins of serpentine so characteristic for this mineral. According to the microprobe analysis (Table 2, probe 1) olivine grains are fairly uniform in composition. The content of the fayalite minal $\left(\mathrm{Fe}_{2} \mathrm{SiO}_{4}\right)$ in olivine varies from 41 to $54 \mathrm{~mol} \%$, which corresponds to the composition of the hortonolite. Plagioclase in the izrandites is distributed unevenly. Its number varies between $2-15 \%$, an average of about $8 \%$ of the rock volume. They cement subeuhedral crystals of clinopyroxene and olivine (Figure 4). Plagioclase refers to labrador No 51-54. On contact with olivine crystals in plagioclase coronary (kelyphytic) structures always develop. Such structures are not fixed on the border with the clinopyroxene grains. In kelyphytic rims around an olivine grains, a thin colorless zone directly on the surface of olivine is composed of the columnar aggregate of crystals of colorless enstatite (Figure 5). Amphibole in equant predominantly participates in the structure of kelyphytic rims around olivine grains. The average content of amphibole clusters in the izrandites is about $6 \%$ of the volume. Amphibole from kelyphytic rims is defined as pargasite, and some - as magnesiogastingsite or kersutite (Table 2, probes 4-6). Amphibole in the Moon rocks is rare [20], but the detection of water in volcanic glasses, minerals and anorthosites of the Moon [26, 10] suggests that there will be more such finds. In this sense, the presence of amphiboles in the izrandite appears to be natural. In kelyphytic rims there are very thin plates of spinel (hercinite) too. Its content in the rock ranges from 1 to $4.5 \%$, an average of $2.5 \%$ of the rock volume. In the intergranular space of crystals of clinopyroxene and olivine, many fine grains of magnetite, ilmenite, and rarely spinel and sulphides (pyrite, pyrrhotite, chalcopyrite, and sphalerite) are scattered in the herring. Their total number does not exceed $1-2 \%$ of the rock volume. Sizes are within the range of $0.01-1.1 \mathrm{~mm}$. Magnetite contains a noticeable admixture of titanium, aluminum, vanadium, and chromium. Characteristically, there are systems of decay plates of different composition. The most numerous are the plates of ilmenite, which are intersected by a later system of mutually perpendicular spinel plates. Spinel in composition corresponds to hercynite. Hercynite also composed of larger grains in intergrowths with ilmenite and magnetite (Table 2, probe 7). According to the olivine-clinopyroxene geothermometer [17], the crystallization temperature of the rock is defined as $940^{\circ} \mathrm{C}$. According to the amphibole geobarometer [8], the composition of the predominant amphiboles of pargasite (Table 2, probe 4) is estimated at $0.9 \mathrm{GPa}$. For the composition of kersutite (Table 2, probe 6), the pressure is $0.83 \mathrm{GPa}$. In all volume of the izrandite the olivine grains bordering the plagioclase (and only with it) are surrounded by a zone of kelyphytic rim. There were no relicts of coronary structures in amphibolites developing on the basis of izrandites. This allows us to deny the appearance of kelyphytic rims around olivine grains as a result of metamorphic transformation of the original rocks. Where these transformations are present, coronary structures, on the contrary, disappear. The structure of the izrandite is typical cumulative (Figure 4), similar to that in the rocks of the basic stratified intrusives (Scergaard, Bushveld, and Stillwater etc). The cumulates are crystals of clinopyroxene and olivine, intercumulus is represented by plagioclase (labrador) and amphibole (pargasite, kersutite). Highly ferruginous (40$54 \%$ ) olivine of izrandites are similar to olivines from gabbro, troctolites, norites, pyroxenites, and anorthosites of layered intrusives in the foundation of ancient and young platforms, in middle massifs $[27,28,30]$, including the pyroxenites of the zonal massifs of the Platiniferous Belt of the Urals [11]. In combination with the characteristic cumulative structure of the izrandites, this allows us to say that the izrandites - the relicts of the original rocks (pyroxenites) preserved from the amphibolite facies of metamorphism from the Proterozoic stratified intrusive complex. The structure of the izrandites, the absence of chemical zoning of their crystals in accordance with the representations [31] make it possible to compare these rocks with orthocumulates. Xenomorphic excretions of the nonzonal labrador between dark-colored minerals, often containing their poikilitic inclusions, represent a crystallized intercumulative liquid. In the izrandites we see the fragments of the rocks of the ancient layered intrusives of the ultrabasite-anorthosite composition, which were preserved within the extended wedges of the non-feldspar amphibolites (Aleksandrovskiy complex) formed on them in the western part of the Ural fold belt (Figure 1), adjacent to the basement of the foundation of the Eastern European continent (Taratash block). It is quite probable that olistolites of rocks exotic for the Urals (various hornblendites, clinopyroxenites, websterites, gabbroids, and apatite-olivine-spinel rocks, etc., which often shown signs of stratification), which lie in the form of detachments among the quartzite matrix of the metamorphosed olistostrome of the Il'meny Mountains [13]. The small dimensions of such blocks, their rootless shape, the variety of composition, fragments of magmatic 
stratification - all this resembles the geological situation with small dispersed mafic-ultramafic bodies of the Belomorsky

druzite complex [28].

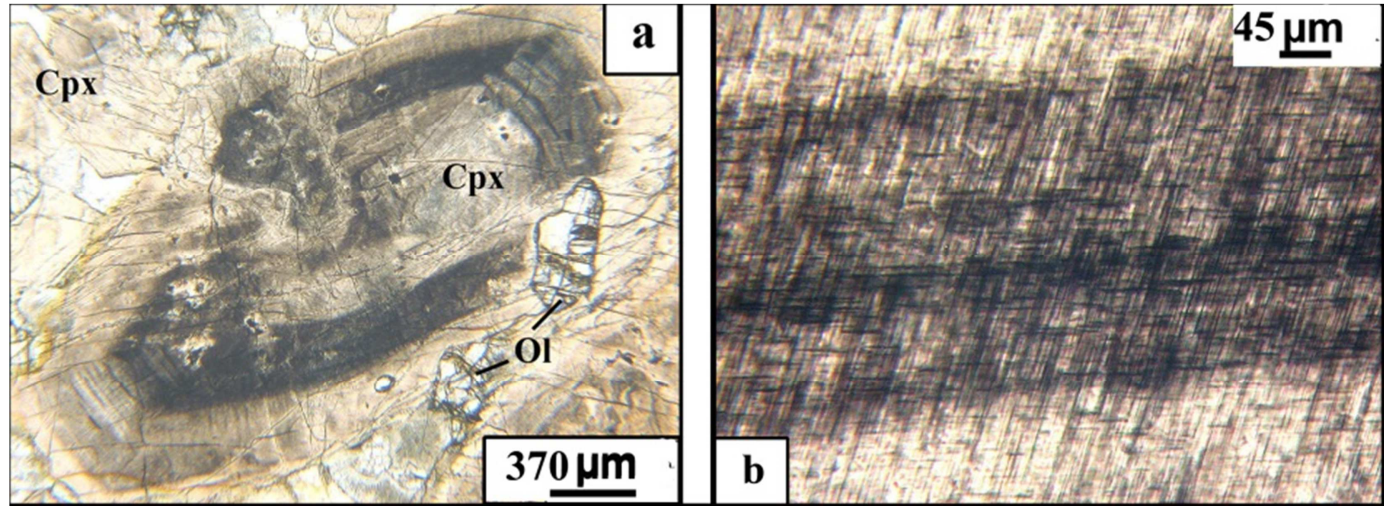

Figure 3. Morphology and internal structure of clinopyroxene crystals (diopside). Photos of the thin sections, without an analyzer. (a) - dark bands parallel to the faces of the crystals are caused by clusters of thin plates of ilmenite, (b) - detail of the structure of the dark band in the cut of the diopside crystal. Thin parallel dark plates of ilmenite. Abbreviations: Cpx-clinopyroxene (diopside), $\mathrm{Ol}$-olivine.

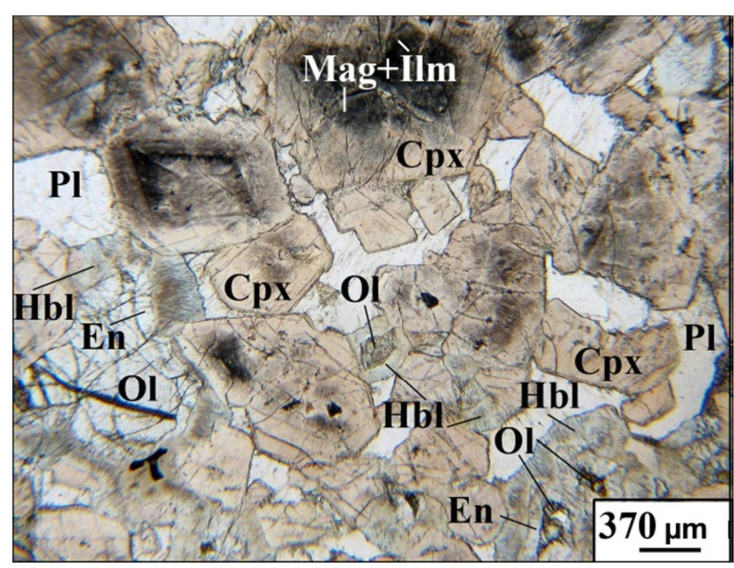

Figure 4. Cumulate structure of the izrandites with coronary sites. Photos of the thin-section, without an analyzer. Abbreviations: Pl-plagioclase, Cpxclinopyroxene (diopside), Ol-olivine, En-enstatite, $\mathrm{Hbl}$ - amphibole, Mag - magnetite, Ilm-ilmenite.

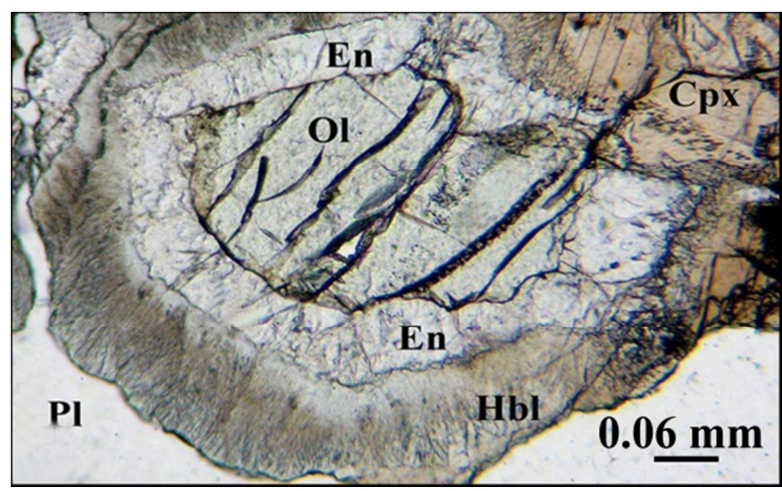

Figure 5. Structure of kelyphytic rims around of olivine grains. Photos of the thin section, without an analyzer. The distinct zonal structure of the kelyphytic rim: the outer zone is the columnar aggregate of green amphibole grains, below is the zone of colorless clinoenstatite, in the center is a colorless olivine core. Abbreviations: Cpx-clinopyroxene (diopside), $\mathrm{Ol}-$ olivine, En-enstatite, $\mathrm{Hbl}$ - amphibole.

Table 2. Chemical composition (wt.\%) of minerals from izrandite (Korinevsky and Kotlyarov 2009).

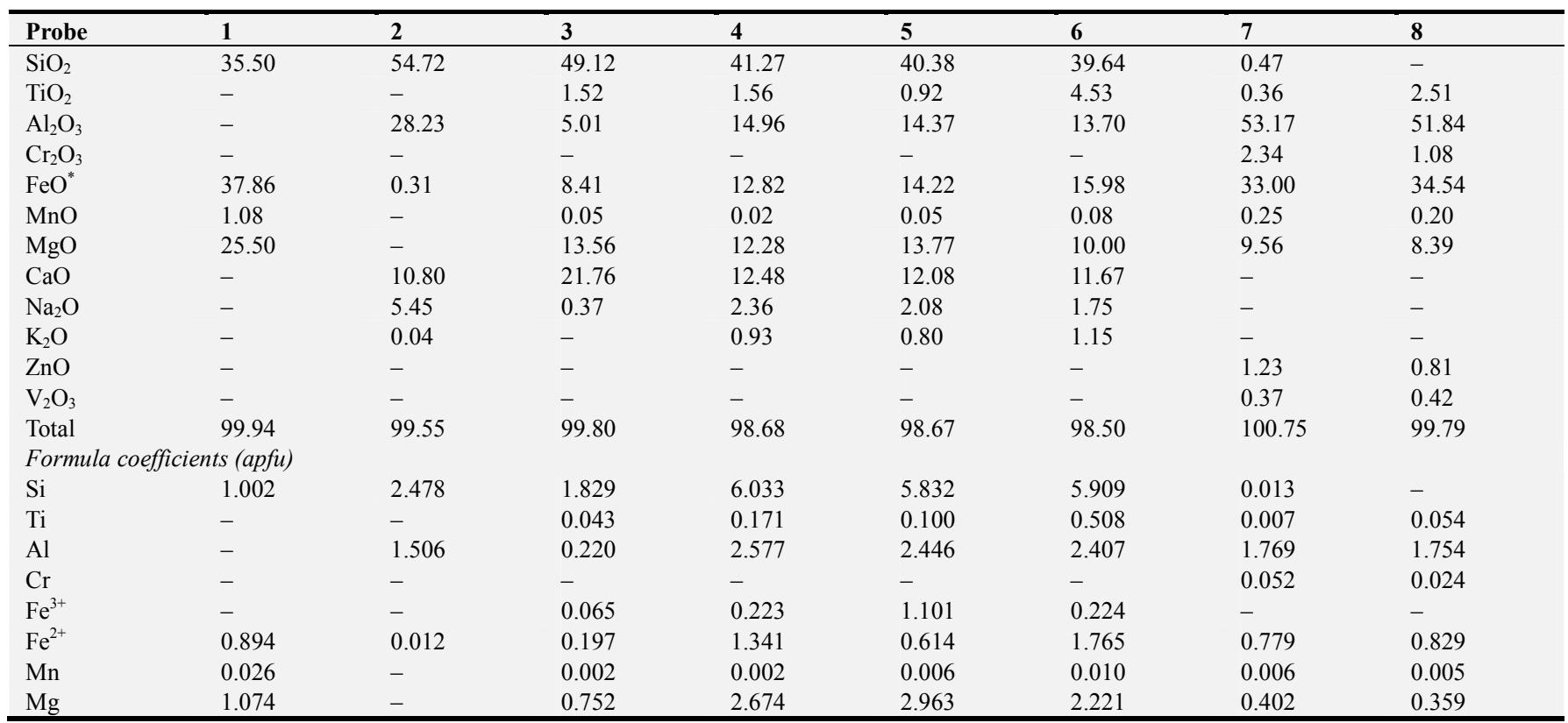




\begin{tabular}{lllllllll}
\hline Probe & $\mathbf{1}$ & $\mathbf{2}$ & $\mathbf{3}$ & $\mathbf{4}$ & $\mathbf{5}$ & $\mathbf{6}$ & $\mathbf{7}$ & $\mathbf{8}$ \\
$\mathrm{Ca}$ & - & 0.524 & 0.868 & 1.954 & 1.869 & 1.863 & - & - \\
$\mathrm{Na}$ & - & 0.478 & 0.027 & 0.668 & 0.582 & 0.505 & - & - \\
$\mathrm{K}$ & - & - & - & 0.173 & 0.147 & 0.219 & - & - \\
$\mathrm{Zn}$ & - & - & - & - & - & - & 0.026 & 0.017 \\
$\mathrm{~V}$ & - & - & - & - & - & - & 0.008 & 0.009 \\
$\mathrm{f}=\mathrm{Fe}^{2+} / \mathrm{Fe}^{2+}+\mathrm{Mg}$ & 0.29 & & 0.21 & 0.33 & 0.17 & 0.44 & 0.66 & 0.70 \\
\hline
\end{tabular}

Note. 1 - olivine, 2 - plagioclase (labrador No 52), 3- clinopyroxene (diopside), 4-6-amphiboles from grains between crystals of clinopyroxene and olivine: 4 - pargasite, 5 - magnesiohastingsite, 6 - kersutite, 7 - spinel (hercinite) from the bulk of the rock, 8 - magnetite from relatively large grains, dash - no data.

\section{Comparison with Lunar Rocks}

Thanks to the efforts of the American astronauts and the results of flights of the Soviet unmanned air vehicles, the world has received a unique possibility to study the composition of rocks from another planets, first of all from the Moon. A fundamental similarity of the lunar and Earth rocks has been established, the magmatic origin of the majority of lunar rocks and relative mineral deficiency in them [3, 4, 7, 18-21].

On the A-S diagram of the lunar rocks composition, where $\mathrm{A}=\mathrm{Al}_{2} \mathrm{O}_{3}+\mathrm{CaO}+\mathrm{Na}_{2} \mathrm{O}+\mathrm{K}_{2} \mathrm{O}$, and $\mathrm{S}=\mathrm{SiO}_{2}-(\mathrm{FeO}+$ $\mathrm{MgO}+\mathrm{TiO}_{2}+\mathrm{MnO}+\mathrm{Cr}_{2} \mathrm{O}_{3}$ ), points of composition of the izrandites from the Mount Karandash, described above ( $\mathrm{A}=$ 43.23; $\mathrm{S}=36.31$ ) fells within the margins of highland rocks of the so-called ANT group (anorthosite, norite, and troctolite) of the Moon [9, 3]. On the classifying diagram $\mathrm{MgO}-\mathrm{Al}_{2} \mathrm{O}_{3}$ [4] they lies within the field of the lunar ferroan noritic anorthosites compositions [20], which prevail on the lunar surface. These rocks are brought together by their very high levels of alumina and calcium, a low amount of alkalis and magnesium oxide and comparable amounts of silica and iron.

Thus, some resemblance to petrochemistry is observed between some gabbro from the regolith of Apollo-11, troctolites, norites [9], and the ferro-norite anorthosites of the North Crater ray [20]. Undoubtedly, the lunar rocks differ from the terrestrial ones by their increased levels of $\mathrm{FeO}$, $\mathrm{MgO}, \mathrm{TiO}_{2}$, and lower $\mathrm{Al}_{2} \mathrm{O}_{3}, \mathrm{CaO}$, and $\mathrm{Na}_{2} \mathrm{O}$, but the quantities of $\mathrm{SiO}_{2}, \mathrm{MnO}$, and $\mathrm{K}_{2} \mathrm{O}$ in them are comparable. At the same time, the gabbro of the Moon, as well as the izrandites have similar distribution. [7] has been found that lunar plagioclases (unlike the terrestrial ones) are characterized by the $\mathrm{Si}$ excess and $\mathrm{A} 1$ deficiency. Surprisingly enough, the plagioclase from the izrandite (Table 2, probe 2) has the Si excess and A1 deficiency as well! The similarity between granulometric composition of lunar and terrestrial rocks is just as remarkable: in the compared varieties the size of mineral grains seldom exceeds 0.3-0.5 $\mathrm{mm}$ in diameter.

Mineral composition of the Moon rocks especially close to izrandite. They contain minerals with a large amount of $\mathrm{TiO}_{2}$, $\mathrm{FeO}, \mathrm{MgO}$, and $\mathrm{CaO}$. Minerals do not demonstrate any notable chemical zonation $[7,18,4]$. The extremely high iron content of olivine in the izrandites sharply distinguishes this variety of plagioclase pyroxenites from petrographically similar pyroxenites of folded regions, including the Platinumbearing belt of the Urals, in which the iron content of olivine practically does not rise above 10-25 mol\% [11]. This high iron content of olivine is not fixed in any of the melanocratic basic and ultrabasic magmatic rocks of the folded regions, but it is characteristic of olivine from the ferroan noritic anorthosites of the Moon [20, $\mathrm{f}=0.45]$. Trace elements in plagioclase and high-Ca pyroxenes found in lunar ferroan anorthosites and trace elements in izrandites are characterized by sharp predominance of LREE. In comparison with rocks of the Moon, the terrestrial izrandites have elevated contents of trace and rare-earth elements (Table 3), but the nature of the distribution of REE in the izrandites is close to that in the rocks of the lunar continents, particularly with ferroan anorthosites (Figure 6, Table 3, probe 4) and troctolites (Figure 6, Table 3, probe 2).

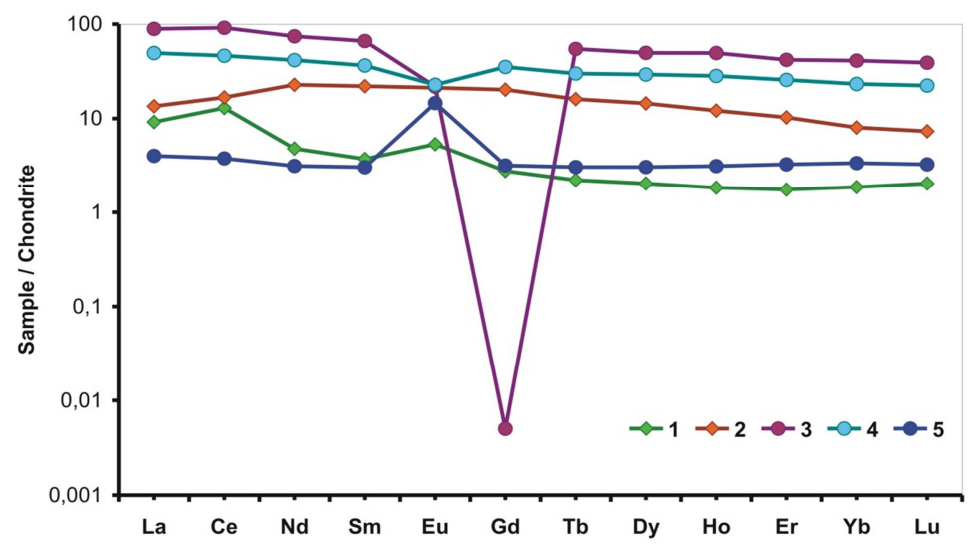

Figure 6. Chondrite-normalized REE patterns for some terrestrial and lunar rocks.

The data for constructing the diagram is shown in Table 3. 2 - terrestrial rock (izrandite); lunar rocks: 3 - troctolites, 4 - norite-troctolite, 5 - ferroan noritic troctolite. 
Table 3. Concentrations of major elements (wt\%) and trace elements (ppm) in the terrestrial and lunar rocks.

\begin{tabular}{|c|c|c|c|c|c|}
\hline Probe & 1 & 2 & 3 & 4 & 5 \\
\hline $\mathrm{SiO}_{2}$ & 46.22 & 45.02 & 48.5 & 46.3 & 45.10 \\
\hline $\mathrm{TiO}_{2}$ & 0.26 & 2.30 & 0.65 & 0.85 & 0.18 \\
\hline $\mathrm{A}_{2}{ }_{2} \mathrm{O}_{3}$ & 22.66 & 7.41 & 22.4 & 24 & 28.26 \\
\hline $\mathrm{FeO}$ & 7.38 & 13.03 & 5.47 & 5.29 & 5.48 \\
\hline $\mathrm{MnO}$ & 0.15 & 0.23 & 0.07 & 0.07 & 0.08 \\
\hline $\mathrm{MgO}$ & 2.12 & 13.77 & 9.29 & 5.29 & 4.29 \\
\hline $\mathrm{CaO}$ & 19.40 & 16.05 & 13.4 & 15.2 & 16.26 \\
\hline $\mathrm{Na}_{2} \mathrm{O}$ & 1.10 & 1.14 & 0.57 & 0.62 & 0.32 \\
\hline $\mathrm{K}_{2} \mathrm{O}$ & 0.07 & 0.13 & 0.25 & 0.14 & 0.02 \\
\hline Total & 99.36 & 99.08 & 100.6 & 97.76 & 99.99 \\
\hline $\mathrm{La}$ & 2.17 & 3.20 & 21.1 & 11.7 & 0.95 \\
\hline $\mathrm{Ce}$ & 7.91 & 10.25 & 56 & 28.4 & 2.31 \\
\hline $\operatorname{Pr}$ & 0.48 & 1.762 & - & - & 0.31 \\
\hline $\mathrm{Nd}$ & 2.19 & 10.39 & 34 & 19 & 1.43 \\
\hline $\mathrm{Sm}$ & 0.55 & 3.25 & 9.8 & 5.4 & 0.45 \\
\hline $\mathrm{Eu}$ & 0.30 & 1.19 & 1.23 & 1.28 & 0.82 \\
\hline Gd & 0.55 & 4.02 & 0.001 & 7 & 0.63 \\
\hline $\mathrm{Tb}$ & 0.08 & 0.58 & 1.97 & 1.08 & 0.11 \\
\hline Dy & 0.5 & 3.56 & 12.2 & 7.2 & 0.75 \\
\hline Но & 0.10 & 0.66 & 2.7 & 1.54 & 0.17 \\
\hline $\mathrm{Er}$ & 0.28 & 1.64 & 6.7 & 4.1 & 0.52 \\
\hline $\mathrm{Tm}$ & 0.04 & 0.22 & - & - & - \\
\hline $\mathrm{Yb}$ & 0.30 & 1.29 & 6.6 & 3.74 & 0.54 \\
\hline $\mathrm{Lu}$ & 0.05 & 0.18 & 0.96 & 0.55 & 0.08 \\
\hline Co & 14.14 & 60 & 31.1 & 23.8 & 16 \\
\hline $\mathrm{Cr}$ & 12.64 & 656 & 1110 & 730 & - \\
\hline Cs & - & - & 0.27 & 0.13 & - \\
\hline $\mathrm{Ga}$ & - & - & 3.05 & 4.08 & - \\
\hline Hf & 0.44 & 2.36 & 7.8 & 4.3 & 0.26 \\
\hline $\mathrm{Ni}$ & 39.89 & 121.5 & 540 & 350 & 49 \\
\hline $\mathrm{Rb}$ & 3.41 & 2.43 & 6 & 3 & 0.50 \\
\hline $\mathrm{Sc}$ & 4.4 & 79.2 & 7.8 & 9.4 & 11.2 \\
\hline
\end{tabular}

Note. 1 - anorthite hedenbergite gabbro of the Ilmeny Mountains [13]; 2 izrandite from the Taratash complex, the South Urals [14]; 3-5 - lunar rocks, Apollo 16 [9], samples: 3 - troctolite 64455, 4 - norite-troctolite 67629, 5 ferroan noritic anorthosite 67215 [20], dash - no data.

\section{Discussion}

The Moon is dominated by anorthite rocks, containing in large quantities of ilmenite, olivine, pyroxenes, and spinel. It is this set of minerals that is characteristic of the earliest rocks of the Urals, the izrandites (Table 2). All this rocks contain large quantities of pyroxene or \pm olivine, ilmenite, and spinel. [21], contrary to the "established" lunar petrogenesis model $[12,6,19]$ found that the Moon is not a "dry" planet, but was formerly a rich water and volatile, which were then removed by degassing this celestial body. This circumstance also explains the depletion of the Moon's rocks by such elements as $\mathrm{P}, \mathrm{Na}, \mathrm{K}, \mathrm{Rb}, \mathrm{Cs}$, and amphibolepoorness of the rocks. All these signs are also characteristic of the izrandite. May be necessary to agree with the views of A. A. Yaroshevsky [34] on the formation of lunar and terrestrial crusts as a result of the accumulation of the products of hardening of separate portions of high-alumina melt, arisen from the depths of planets as a result of zone smelting. These Moon rocks comprise a significant part of the volume of the relatively thin crust, and in the Earth conditions they have hardened in the bottom layers of the powerful continental crust section. It could be this fact is to be accounted for why such gabbro occurs rarely on the Moon surface. On the Earth, izrandites are also very rare rocks. Fragments of these rocks have appeared on the surface of the Earth protrusions of serpentinite mélange or are preserved as relicts in the ancient metamorphic rocks. Geologists at the moment suggest that the anorthosites of the layered intrusive complexes of the Earth (e.g. Sept Iles intrusive from Canada) were formed by means of the accumulation of floated plagioclase grains initially crystallized at the bottom of the Earth crust, just like it occurs on the Moon.

How can we explain the presence on Earth of rare species of rocks in which we see analogues of some rocks of the lunar highlands? The rocks that now form the basis of the earth's crust, during formation (more than 1.8 billion years ago) were part of the outer shell of the planet Earth. Much later, they were covered by a powerful sedimentarymetamorphic complex of rocks, which is now exposed in the foundations of platforms, shields, and in folded belts. There are no such formations on the Moon, but many scientists believe that active geological activity on this planet ceased 34 billion years ago, and this planet has since been a cold sphere. According to the American astronauts E. Serna and H. Schmitt [2], they found evidence of "recent" volcanic activity on the Moon (Shorty crater) in the form of orange spots oxidized by the hot gases of volcanic glass beads and black volcanic ash. The discovery of lobed slopes (escarpes) up to $100 \mathrm{~m}$ in height and several kilometers long, crossing the youngest meteorite craters, on the "living" surface of the Moon also speaks of it. As suggested by the authors of the study [32], such escarps arise due to compression (wrinkling) of the lunar surface due to the cooling of its inner layers. This process started about 1 billion years ago and is happening now. It is possible to assume synchronous rocks from the surface of the Moon and igneous rocks of the Earth's crust base. In this sense, we can consider the olivine pyroxenites (izrandites) described by us, are the analogues of some anorthite gabbroids of the lunar highlands. On the surface of the Earth, such formations are sometimes carried out in the form of fragments by protrusions of serpentinite melange in folded belts.

Thus, evidence has emerged of the presence on the Moon of rocks that are significantly younger than is commonly believed (4.36 billion years old [5]. Among them may be mafic rocks, similar in composition to the izrandites, maybe even the same age with them.

\section{Conclusions}

The anorthite rocks predominate on the Moon contain large quantities of ilmenite, olivine, pyroxenes, and spinel. It is this set of minerals that is characteristic of the oldest rocks of the Urals (izrandites) (Table 2). Compared with the ferrous anorthosites of the Moon, terrestrial izrandites have elevated contents of small and rare-earth elements 
(Table 3). The extremely high iron index of olivine in izrandites sharply distinguishes this type of plagioclase pyroxenite from petrographically similar pyroxenite in folded regions, including the Ural Platinum belt, in which the iron index of olivine practically does not rise above $10-25 \mathrm{~mol} . \%$

The variation in the composition of rocks and different character of their placement in the sections of the modern Earth and Moon are explained fairly well by the two-stage mechanism of planet formation due to the collision of the primary "germs" followed by the release of debris to the orbit, which has formed the Moon. As it is expected, these were the mainly high calcic and aluminous rocks from the Moon surface that used to compose the inner part of the original "germs" of the Earth. We believe that the finding of the anorthite hedenbergite gabbro and izrandites on the Earth will help to find such rocks on the Moon as well.

\section{Acknowledgements}

We are grateful to Dr. V. A Kotlyarov (Institute of Mineralogy UB of RAS, Miass) for his help with the work on the SEM. Special thanks to Ekaterina Khrenova for assistance in translation of the text, and Valentina Sval'nova for informational assistance.

\section{References}

[1] Anfilogov VN, Khatchay YV, Antipin AN (2015) About relationship of the compositions of matter of the Moon, primary Earth crust and mantle. Lithosphere 1: 109-115 (in Russian).

[2] Apollo 17. Mission report (1973) Lyndon B. Johnson center, Houston. Texas.

[3] Barsukov VL, Dmitriev LV, Garanin AV (1979) Basic features of geochemistry of Lunar rocks. In: Ground from continental area of the Moon. Nauka, Moskow, pp 18-30 (in Russian).

[4] Bogatikov OA, Gon'shakova VI, Frikh-Khar DI. (1983) Classification of lunar igneous rocks and their comparison with terrestrial analogues. In: Sharkov EV (ed.), Magmatic rocks III. Nauka, Moscow, pp 395-402 (in Russian).

[5] Borg LE, Connely JN, Boyet M, Carlson RW (2011) Chronological evidence that the Moon is either young or did not have a global magma oceprobe Nature 477 (7362): 70-72.

[6] Delano JW (2009) Scientific exploration of the Moon. Elements 5: 11-16.

[7] Frondel JW (1975) Lunar mineralogy. Wiley, New York, London.

[8] Hammarström JM, Zen E-An (1986) Aluminium in hornblende: an empirical igneous geobarometer. Am Miner 71: $1297-1313$.

[9] Haskin LA, Helmke HA, Blanchard DP, Jacobs JW, Telander K (1973) Major and trace elements abundaces in samples from the lunar highlands. In Proceedings of the Fourth Lunar Science Conferens (Supplement 4). Geochim Cosmochim Acta 2: 1275-1296.
[10] Hui HJ, Peslier AH, Zhang Y, Neal CR (2013) Water in lunar anorthosites and evidence for a wet early moon. Nature Geosci 6: 177-180.

[11] Ivanov OK (1997) Concentric-zonal pyroxenite-dunite massifs of the Urals. Urals University Publ, Ekaterinburg (in Russian).

[12] Jolliff BL, Wieczorek MA, Shearer CK, Neal CR (2006) New Views of the Moon. Rev Mineral Geochem 60.

[13] Korinevsky VG, Korinevsky EV (2006) The new in geology, petrography and mineralogy of the Il'meny Mountains. IMIN UB RAS, Miass (in Russian).

[14] Korinevsky VG, Kotlyarov VA (2009) Mineralogy of plagioclase-olivine clinopyroxenite (izrandite) of the Urals. Lithosphere 4: 27-40 (in Russian).

[15] Krasnobaev AA, Cherednichenko SV (2004) Zircon geochronology of the Alexandrovskiy metamorphic complex (South Urals). Doklady of RAS 396 (4): 519-523 (in Russian).

[16] Lennykh VI, Valizer PM (2006) To the geological scheme of the Il'menogorskiy complex. In: Geology and mineralogy of the Il'menogorskiy complex: situation and problems. Il'menian Reserve Publ, Miass, pp 20-27 (in Russian).

[17] Loucks RR (1996) A precise olivine-augite $\mathrm{Mg}-\mathrm{Fe}$ exchange geothermometer. Contrib Mineral Petrol 125 (2-3): 140-150.

[18] Nazarov MA, Tarasov LS, Shevaleevsky ID (1979) Mineralogy of mainland regolith ("Moon-20"). In: Ground from continental area of the Moon. Nauka, Moscow, pp 226266 (in Russian)

[19] Neal CR (2009) The Moon 35 years after Apollo: What's left to learn? Chemie der Erde 69: 3-43.

[20] Norman MD, Borg LE, Nyquist LE, Bogard DD (2003) Chronology, geochemistry, and petrology of a ferroan noritic anorthosite clast from Descartes breccia 67215: clues to the age, origin, structure, and impact history of the lunar crust. Meteor Planet Sci 38 (4): 645-661.

[21] O'Hara MJ, Niu YL (2015) Obvious problems in lunar petrogenesis and new perspectives. In: The interdisciplinary earth: a volume in honor of Don 1. Anderson. Boulder, Colorado: The Geological Society of America, the American Geophysical Union, pp 339-366.

[22] Ovchinnikov LN Dunaev VA (1968) About geological oldest deep rock of the Urals. In: Deep structure of the Urals. Nauka, Moscow, pp 200-209 (in Russian).

[23] Pystin AM (1978) Aleksandrovskiy gneiss-amphibolite complex. In: Volcanism, metamorphism and ferruginous quartzites of the Taratash complex. UNTs of the USSR Academy of Sciences, Sverdlovsk, pp 3-32 (in Russian).

[24] Pystin AM, Pystina SN, Lennykh VI (1973) About geological setting of izrandites in the Alexandrovskiy complex (western slope of the Urals). In: Ezhegodnik-1972 of the IGG UB RAS, Sverdlovsk, pp 96-97 (in Russian).

[25] Ronkin YuL, Sindern S, Kramm U, Lepikhina OP (2008) Isotopic geology of the earliest formations of the Urals: U$\mathrm{Pb}, \mathrm{Sm}-\mathrm{Nd}, \mathrm{Rb}-\mathrm{Sr}$ and ${ }^{40} \mathrm{Ar}-{ }^{39} \mathrm{Ar}$ systematics. In: Structural-real complexes and problems of geodynamics Precambrian of the Phanerozoic orogens. UB RAS, Ekaterinburg, pp 117-120. 
[26] Saal AE, Hauri EH, Lo Cascio M, Van Orman JA, Rutherford MC, Cooper RF (2008) Volatile content of lunar volcanic glasses and the presence of water in the Moon's interior. Nature 454: 192-195.

[27] Sharkov EV, Bogatikov OA (1983) Layered intrusions of basic and ultrabasic rocks. In: Sharkov EV (ed.), Magmatic rocks III. Nauka, Moscow, pp 72-103 (in Russian).

[28] Sharkov EV, Krasivskaya IS, Chistyakov AV (2004) Dispergeric mafite-ultramafite intrusive magmatism of the Early-Paleoproterozoic mobil zones of the Baltic shield: e.g. druzite (coronite) complex of the Belomoriya. Petrology 12 (6): 632-655 (in Russian).

[29] Smith JV (1980) Was a hydrous and carbonated magma present on the Moon? Lunar Planet Sci XII: 1005-1007.

[30] Tomilenko AA, Kovyazin SV (2008) Formation of the coronite structures around olivine in the Korosten pluton anorthosites, Ukranian shield: mineralogy, geochemistry, fluid inclusions. Petrology 16 (1): 92-109 (in Russian).

[31] Wager LP, Brown GM (1968) Layered igneous rocks. Oliver \& Boyd, Edinburg, London.

[32] Watters TR., Robinson M, Beyer RA, Banks ME, Bell J, Pritchard ME, Williams NR (2010). Evidence of recent thrust faulting on the moon revealed by the lunar reconnaissance orbiter camera. Science 329 (5994): 936-940.

[33] Whitney DL, Evans BW (2010) Abbreviations for names of rock-forming minerals. Am Mineral 95: 185-187.

[34] Yaroshevsky AA (1979) Zonal melting of the Lunar crust rocks. In: Ground from continental area of the Moon. Nauka, Moscow, pp 327-335 (in Russian). 